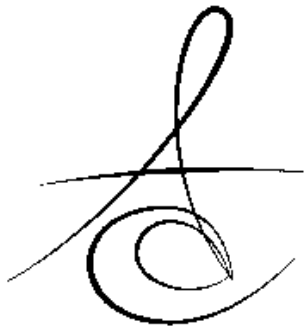

\title{
MAXILLARY SINUS LIFTING PROCEDURES USING XENOGENEIC CORTICO- CANCELLOUS GRAFT MATERIAL WITH SIMULTANEOUS IMPLANT PLACEMENT: A 1- TO 3-YEAR FOLLOW-UP
}

\section{KSENOJEN KORTİKOKANSELLÖZ GREFT MATERYALİ KULLANILAN MAKSİLLER SİNÜS TABANI YÜKSELTİLMESİ PROSEDÜRÜYLE EŞ ZAMANLI IMMPLANT YERLEŞTİRİLMESİ: 1 - 3 YILLIK TAKİP}

Yrd. Doç. Dr.Adnan KILINÇ*

Prof. Dr. Ertunc DAYI

Yrd. Doç. Dr. Mert ATAOL ${ }^{* *}$

Makale Kodu/Article code: 3061

Makale Gönderilme tarihi: 16.10 .2016

Kabul Tarihi: 15.12 .2016

\section{ABSTRACT}

Aim: The aim of this study was to evaluate retrospectively the clinical outcomes of laterally approached sinus floor lifting with xenografts and simultaneously dental implant placement procedures.

Material and Methods: All patients treated with sinus lifting and simultaneous implant placement procedure and were followed for at least 1 year were retrospectively selected for this study. The lateral window technique was performed using a xenogeneic cortico-cancellous grafting material and bone-level implants were placed immediately. Survival rates of implants and clinical features of patients and implants were evaluated.

Results: A sample of 30 patients, 42 implants were placed according to the one-stage approach. Residual preoperatively alveolar ridge height varied between 3 and $6 \mathrm{~mm}$ with a mean of $4.58 \mathrm{~mm}$ and the bone gain at 1-year follow-up varied between $6 \mathrm{~mm}$ and $10 \mathrm{~mm}$ with a mean of $8.6 \mathrm{~mm}$. Only two implants were lost before loading and overall survival rate was $96 \%$ for the implant-based analysis.

Conclusions: Maxillary sinus lifting procedure with xenogeneic cortico-cancellous graft material and simultaneously implant placement was showed as a predictable and successful treatment modality.

Keywords: Biomaterials, dental implant, sinus floor augmentation, xenograft

\section{öz}

Amaç: $\mathrm{Bu}$ çalışmanın hedefi ksenogreft kullanılan lateral yaklaşım ile maksiller sinüs tabanı yükseltilmesi ve eş zamanlı implant yerleşimi işleminin klinik sonuçlarının retrospektif olarak değerlendirilmesidir.

Gereç ve Yöntem: Tüm hastalara sinus tabanı yükseltme işlemi ile eş zamanlı implant yerleşimi uygulanmış ve en az 1 yıl süreyle takip edilmiştir. Hayvan kaynaklı kortikokansellöz greft materyali ve lateral pencere tekniği uygulanmış ve aynı esnada kemik seviyesinde implantlar yerleştirilmiştir. İmplantların sağkalım oranları ve hastaların klinik özellikleri değerlendirilmiştir.

Bulgular: 30 hasta üzerinde tek aşamalı yaklaşım ile 42 implant yerleştirilmiştir. Preoperatif rezidüel alveolar kemik yüksekliği $3 \mathrm{~mm}$ ile $6 \mathrm{~mm}$ arasında değişmektedir ve ortalama $4,58 \mathrm{~mm}$ 'dir ve 1 yıllık takiplerde kemik kazanımı $6 \mathrm{~mm}$ ile $10 \mathrm{~mm}$ arasında değişmektedir ve ortalama $8,6 \mathrm{~mm}$ 'dir. Sadece 2 implant yükleme öncesinde kaybedilmiştir ve implant sağ kalım oranı \%96 olarak görülmüştür.

Sonuç: Ksenojen kortikokansellöz kemik grefti kullanılan maksiller sinus tabanı yükseltme işlemi ile eş zamanlı implant yerleşimi öngörülebilir ve başarılı bir tedavi yöntemi olarak görülmektedir.

Anahtar kelimeler: Biyomateryaller, diş implantı, sinüs taban yükseltmesi, ksenograf

implants require sufficient bone to be adequately stabilized. ${ }^{1-3}$ Following the extraction of teeth, alveolar bone resorption and increased pneumatization of the maxillary sinus cavity frequently limit the quantity and quality of bone in the edentulous posterior maxilla. treatment alternative for replacing missing teeth or improving the retention and stability of removable dental and maxillofacial prostheses. However, dental

\footnotetext{
* Atatürk Üniversitesi Diş Hekimliği Fakültesi Ağız, Diş ve Çene Cerrahisi Anabilim Dalı, Erzurum

** Mersin Üniversitesi Diş Hekimliği Fakültesi Ağız, Diş ve Çene Cerrahisi Anabilim Dalı, Mersin
} 
Thus, various methods was needed to gain necessary bone for successful implant placement. ${ }^{4}$ For such cases, sinus lifting procedure is employed frequently in the dental practice with high predictability and well surgical outcomes. ${ }^{5}$ Maxillary sinus lifting procedure has become widely accepted as a routine method to improve the bone height before implant placement. ${ }^{6-8}$

Several sinus floor elevation techniques have been recommended in the literature to overcome these limitations. For large amount of bone augmentation, a lateral approach was initially described by Tatum ${ }^{9}$ in 1986 . Considering of lateral approach, to decision to place simultaneous implants during the sinus floor elevation (one-stage approach) or at a later date (two-stage approach) depended on whether the crest had sufficient residual bone height to ensure primary stability of the implant. The onestage approach could be described as combining sinus lift and implant placement. One-stage procedure should be considered in sites acceptable primary stability of implants was achieved. ${ }^{10,11}$ Thus, the number of surgical procedures and total treatment time can be reduced. ${ }^{12}$

Bone grafting material selection is one of the crucial factors that affects success of sinus lifting procedure. ${ }^{13}$ All currently used bone grafts, including autogenous bones, allografts, xenografts, composite bones, and alloplastic materials are considered to be safe, but all of them have some advantages and disadvantages. Thereby clinicians should prefer the appropriate grafting material for patient and procedure. ${ }^{14,15}$ However, there is a lack of scientific data on which material should be preferred for sinus lifting procedure. ${ }^{12}$ Xenografts are remarkable grafting materials and clinical studies on survey of xenografts and related implants are needed. ${ }^{16}$

The aim of this study was to evaluate retrospectively the clinical outcomes of laterally approached sinus floor lifting with xenografts and simultaneously dental implant placement procedures. Implant survival rates were evaluated after a follow-up period of 1 to 3 years.

\section{MATERIAL AND METHOD}

The study protocol was approved by local ethical committee of Ataturk University Faculty of Dentistry. Patients affected by bruxism, alcoholism, smoking more than 10 cigarettes per day, taking medicaments interfering with regular healing process, patients with poor oral hygiene, pregnant women, and patients affected by serious systemic diseases were excluded from this study. Patients who underwent laterally approached sinus floor lifting and simultaneously dental implant placement by one surgeon (A.K.) between January 2013 and July 2015 and were followed for at least 1 year were retrieved in this retrospective study. 18 men and 12 women, total 30 patients received an identical surgical protocol that included bone grafting with a xenogeneic corticocancellous grafting material (Gen-Os, Osteobiol, Tecnoss, Torino, Italy).

After local anesthesia (articaine with epinephrine $1: 10,000)$, a midcrestal and two vertical incisions were performed. A mucoperiosteal flap was raised to expose the lateral wall of sinus cavity. Lateral bone window was formed. Then, the sinus mucosa was carefully elevated by using mucosal sinus elevators. If any perforation occurred, they were repaired with bioresorbable collagen membrane. The palatal aspect of the space was filled with a xenogeneic cortico-cancellous grafting material (GenOs, Osteobiol, Tecnoss, Torino, Italy). Implants had appropriate length and diameter was installed in the residual subantral bone. Firm primary stability was achieved for all implants at installation. Primary implant stability was noted manually at installation, where none of the implants showed rotational or lateral instability. And then, the implant fixtures were covered with the rest of the graft material. The implant systems included in this study had submerged design, the same conical fixture design and implantabutment interface design. Then incision was closed primarily with nonresorbable sutures.

Postoperatively, all patients received the same protocol that included antibiotics (amoxicillinclavulanic acid), analgesics (NSAID) and chlorhexidine mouth wash for 1 week. Patients were recalled 1month, 3-month and 6-month after surgery and annually thereafter for clinical and radiographic examination.

Each implant was classified at follow-up period at least 12 months and up to 36 months (mean; 22 months) as successful or failed based on frequently used clinical and radiographic criteria. If the following parameters were absent, the implant was considered 
successful: (1) persistent subjective complaints such as pain, foreign body sensation, and/or dysesthesia, (2) peri-implant infection with suppuration, (3) mobility, or (4) continuous radiolucency around the implant. Removed, lost, mobile, or fractured implants were regarded as implant failures. Kaplan-Meier survival estimate analysis was used to compare implant survival of the study groups.

Vertical residual bone distance from the top of the alveolar crest to the base of the maxillary sinus for all patients obtained from preoperative radiographs. The bone gain defined as the vertical distance from above the ungrafted sinus floor to the lowest point were measured from 1-year postoperative panoramic radiographs. Patients were evaluated in terms of; age, gender, status of edentulism, implant zones and diameter and length of implants.

\section{RESULTS}

In a sample of 30 patients, 33 one-stage sinus lifting procedure using xenogeneic cortico-cancellous graft material was performed and 42 implants were placed simultaneously. The mean age of the patients was 43.6 years (range; 36 to 62 years) at the time of operation (Table 1 ). A total of 18 patients $(60 \%)$ were male and 12 (40\%) were female.

Table 1. Age distribution

\begin{tabular}{|c|c|c|}
\hline Age & Number of Patient & $\%$ \\
\hline $35-40$ & 8 & $27 \%$ \\
\hline $41-45$ & 6 & $20 \%$ \\
\hline $46-50$ & 6 & $20 \%$ \\
\hline $51-55$ & 4 & $13 \%$ \\
\hline $56-60$ & 4 & $13 \%$ \\
\hline $60+$ & 1 & $7 \%$ \\
\hline
\end{tabular}

The distribution of the type of edentulism of patients were as follows; $60 \%$ (18) of regions were partially edentulous area located posterior to the remaining natural teeth (free-end) ; 20\% (6) were partially edentulous area with natural teeth both anterior and posterior to the area (tooth-end); $17 \%$ (5) were total edentulism and 3\% (1) were single tooth edentulism. The most performed implant positions were respectively, upper first molar, upper second molar and upper second premolar.

At baseline, residual preoperatively ridge height varied between 3 and $6 \mathrm{~mm}$ with a mean of $4.58 \mathrm{~mm}$. The bone gain at 1-year follow-up (the height of endosinus new bone) varied between $6 \mathrm{~mm}$ and 10 $\mathrm{mm}$ with a mean of $8.6 \mathrm{~mm}$. It was showed that $10 \mathrm{~mm}$ length was the most performed length of all implants (86\%). The diameters of 42 implants ranged from $3.3 \mathrm{~mm}$ to $4.8 \mathrm{~mm}$ and the most performed was $4.3 \mathrm{~mm}$ (54\%).

At the end of the follow-up period, the overall survival rate of implants was $96 \%$ using the KaplanMeier survival estimate method. Only two implants were lost during the preloading follow-up period.

\section{DISCUSSION}

Retrospective analysis of clinical outcomes of dental implants and sinus lifting procedures were quite important in terms of providing guidance to clinicians. ${ }^{17-19}$ The overall long-term failure rate is related with the bone quality and quantity. Beside several procedures and materials for augmenting bone height, sinus lifting has become a standard procedure to gain bone height in the posterior maxilla for placement of long dental implants. ${ }^{20}$

In this study, panoramic radiographs which have overestimated the need for sinus augmentation were used for pretreatment planning. ${ }^{21}$ Because all implants which were used in this study had the same design type and same surface characteristics, although the potential differences between implant systems could be disregarded.

In a study included 731 patients applied simultaneously with maxillary sinus lifting, male: female ratio of patients was $2: 3 .^{22}$ Conversely, male: female ratio of our study was 3:2.

Zinser et al. $^{23}$ showed that age was a significant factor of implant failure, however several studies showed that age and sex were not related with early implant failure. ${ }^{19,24,25}$ Mardinger et al. ${ }^{26}$ revealed that there was not a correlation between demographic characteristics including age and sex and the rate of changes after lateral approached sinus floor lifting. Similarly, age and sex did not have an effect on any outcome variables of our study. Alsaadi et al. ${ }^{24}$ considered the type of edentulism to be a risk factor for implant failure and observed a significant increase in failures of implants placed adjacent to teeth. In our study, there was no relationship between the type of

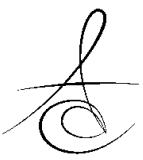


Atatürk Üniv. Diş Hek. Fak. Derg.

J Dent Fac Atatürk Uni

Cilt:28, Sayı:1, Yıl: 2018, Sayfa, 1-6
KILINÇ, ATAOL, DAYI edentulism and implant failures.

Various bone grafting materials could be used in sinus lifting procedure. ${ }^{27}$ The use of autogenous bone graft for augmentation is possible through osteogenesis and osteoinduction, thus shortening the healing period but holds the risk of higher morbidity rate when compared to non-autogenous materials. ${ }^{28}$ Considering the disadvantages of autogenous bone grafting procedures, non-autogenous grafting materials should be seen as an alternative. ${ }^{29}$ Nonautogenous grafting materials show reliable result for sinus floor elevation, with no significant differences in clinical outcomes and implant survival. ${ }^{30}$ In two systematic review, it was showed that there was no significant difference between autogenous and nonautogenous grafting materials in terms of the survival rates of implants placed in maxillary sinus floor elevation site. ${ }^{29,30}$ Xenografts showed similarity with human cancellous bone in terms of its crystalline and morphological structure. In addition, the physical properties of Bio-Oss granulate also approximate to the values for human bone tissue. ${ }^{16}$ Because of these advantages, xenografts, used in this study, are one of the most preferred bone graft material especially for sinus elevation. ${ }^{26}$

$96 \%$ cumulative implant success rate was observed from this study with only two implant failures in preloading period. In a similar study using cortico-cancellous xenografts with 1-stage sinus lifting procedure, the implant survival rate was demonstrated as $98 \%$ after 2 to 6 years follow-up. ${ }^{11}$ Additionally, in a clinical study, a $97 \%$ cumulative survival rate was reported for implants placed after maxillary sinus grafting using alloplastic material (HA or collagen) or xenograft (Bio-Oss). ${ }^{31}$ These high survival rates are consistent with our results for overall implant survival rate after at least 1 year follow-up.

Considering the failed implants, the length of one of failed implants was $10 \mathrm{~mm}$, and the diameters were $3.8 \mathrm{~mm}$. Residual ridge height for this implant was $5.2 \mathrm{~mm}$ preoperatively. The edentulism status of this patient was free-end. The dimensions of the other failed implant were $10 \mathrm{~mm}$ length and $3.8 \mathrm{~mm}$ diameter. Residual preoperatively ridge height was 5.0 $\mathrm{mm}$. The edentulism status of this patient was total edentulism. For assessing the reasons of failure; Tidwell et al. ${ }^{32}$ founded no significant difference in the success rates of implants placed in $<5 \mathrm{~mm}$ bone
( $91 \%$ ) and $>5 \mathrm{~mm}$ bone $(97 \%)$ so residual ridge height was not considered as a failure factor. Alsaadi et al. $^{24}$ stated that bone quality affected implant failure. Because of the retrospective nature of this study, bone quality could not be assessed and this condition could be a reason of failure.

If the residual bone quality and quantity is sufficient to ensure primary stability, implant can be placed simultaneously with sinus lifting. ${ }^{19}$ Borges et al. ${ }^{33}$ showed that positive correlations were detected with the length of implant protruded into the sinus and bone gain. Thor et al. ${ }^{34}$ revealed that the residual bone height was 2 to $9 \mathrm{~mm}$ and the average gain of bone at the sinus floor was $6.51 \mathrm{~mm}$ after a minimum of 1 year follow-up. In addition, Canullo et al. ${ }^{35}$ indicated that the residual bone height was 1 to $4 \mathrm{~mm}$ (mean $2.7 \mathrm{~mm}$ ) with a mean gain of $11 \mathrm{~mm}$. In the present study, the residual bone varied between 3 and $6 \mathrm{~mm}$ with a mean of $4.58 \mathrm{~mm}$ and the average bone gain was $8.6 \mathrm{~mm}$. This diversity among these studies was influenced by the preoperative residual bone height.

\section{CONCLUSION}

Maxillary sinus lifting procedure with xenogeneic cortico-cancellous graft material and simultaneously implant placement if the residual bone is sufficient to ensure primary stability is an effective and safe procedure allowing high survival rates of implants placed in the posterior maxilla. Furthermore, a large-scale study would be required to assess potential modifying factors.

\section{Acknowledgments}

The authors reported no conflicts of interest related to this study.

Adnan Kılınç ORCID ID: 0000-0003-4520-1271

Mert Ataol ORCID ID: 0000-0002-8015-168X

Ertunç Dayı ORCID ID: 0000-0001-7201-2025

\section{REFERENCES}

1. Chang $\mathrm{SH}$, Lin $\mathrm{CL}$, Hsue SS, Lin $\mathrm{YS}$, Huang $\mathrm{SR}$. Biomechanical analysis of the effects of implant diameter and bone quality in short implants placed in the atrophic posterior maxilla. Med Eng Phys 2012;34:153-60. 
doi:10.1016/j.medengphy.2011.07.005.

2. Marx RE. Alveolar Bone Augmentation via In Situ Tissue Engineering. in Tolstunov L, Horizontal Alveolar Ridge Augmentation in Implant Dentistry: A Surgical Manual Wiley: 2015 p:297-310

3. Esposito M, Barausse C, Pistilli R, Sammartino G, Grandi G, Felice P. Short implants versus bone augmentation for placing longer implants in atrophic maxillae: One-year post-loading results of a pilot randomised controlled trial. Eur J Oral Implantol 2015;8:257-68.

4. Jurisic M, Markovic A, Radulovic M, Brkovic BMB, Sandor GKB. Maxillary sinus floor augmentation: comparing osteotome with lateral window immediate and delayed implant placements. An interim report. Oral Surg Oral Med Oral Pathol Oral Radiol Endod 2008;106:820-7. doi:10.1016/j.tripleo.2008.04.025.

5. Umanjec-Korac S, Wu G, Hassan B, Liu Y, Wismeijer D. A retrospective analysis of the resorption rate of deproteinized bovine bone as maxillary sinus graft material on cone beam computed tomography. Clin Oral Implants Res 2014;25:781-5.

6. Jensen OT, Brownd C, Baer D. Maxillary molar sinus floor intrusion at the time of dental extraction. J Oral Maxillofac Surg 2006;64:1415-9.

7. Fugazzotto PA. Sinus floor augmentation at the time of maxillary molar extraction: technique and report of preliminary results. Int J Oral Maxillofac Implant 1999;14:536-42.

8. Doobrow JH, Leite RS, Hirsch HZ. Concomitant oroantral communication repair and immediate implant placement: a five-year case report. Implant Dent 2008; 17: 176-81. doi:10. 1097/ID. 0b013e318166dbe7.

9. Tatum Jr H. Maxillary and sinus implant reconstructions. Dent Clin North Am 1986;30:20729.

10. Galindo-Moreno P, Avila G, Fernandez-Barbero JE, et al. Evaluation of sinus floor elevation using a composite bone graft mixture. Clin Oral Implants Res 2007;18:376-82. doi:10.1111/j.16000501.2007.01337.x.

11. Lambert F, Lecloux G, Rompen E. One-step approach for implant placement and subantral bone regeneration using bovine hydroxyapatite: a 2- to 6year follow-up study. Int J Oral Maxillofac Implants. 2010;25:598-606.
12. Pjetursson $B E$, Tan $W C$, Zwahlen $M$, Lang NP. A systematic review of the success of sinus floor elevation and survival of implants inserted in combination with sinus floor elevation: Part I: Lateral approach. J Clin Periodontol 2008;35:216-40. doi:10.1111/j.1600-051X.2008.01272.x.

13. Galindo-Moreno P, Moreno-Riestra I, Ávila G, et al. Histomorphometric comparison of maxillary pristine bone and composite bone graft biopsies obtained after sinus augmentation. Clin Oral Implants Res 2010;21:122-8.

14. Murugan R, Ramakrishna $S$. Development of nanocomposites for bone grafting. Compos Sci Technol 2005;65:2385-406.

doi:10.1016/j.compscitech.2005.07.022.

15. Karabuda C, Ozdemir O, Tosun T, Anil A, Olgaç V. Histological and clinical evaluation of 3 different grafting materials for sinus lifting procedure based on 8 cases. J Periodontol 2001;72:1436-42.

16. Yildirim M, Spiekermann H, Biesterfeld S, Edelhoff D. Maxillary sinus augmentation using xenogenic bone substitute material Bio-Oss in combination with venous blood. A histologic and histomorphometric study in humans. Clin Oral Implants Res 2000;11:217-29.

17. MacHtei $E E$, Mahler $D$, Oettinger-Barak $O$, Zuabi $O$, Horwitz J. Dental implants placed in previously failed sites: Survival rate and factors affecting the outcome. Clin Oral Implants Res 2008;19:259-64. doi:10.1111/j.1600-0501.2007.01466.x.

18. Wittneben J, Buser D, Salvi GE, Bürgin W, Hicklin S, Brägger $U$. Complication and Failure Rates with Implant-Supported Fixed Dental Prostheses and Single Crowns: A 10-Year Retrospective Study. Clin Implant Dent Relat Res 2014;16:356-64.

19. van Steenberghe $D$, Jacobs $R$, Desnyder $M$, Maffei $G$, Quirynen M. The relative impact of local and endogenous patient-related factors on implant failure up to the abutment stage. Clin Oral Implant Res 2002;13:617-22.

20. Browaeys H, Defrancq J, Dierens MCA, et al. A retrospective analysis of early and immediately loaded osseotite implants in cross-arch rehabilitations in edentulous maxillas and mandibles up to 7 years. Clin Implant Dent Relat Res 2013; 15:380-9. doi:10.1111/j.1708.8208.2011.00367.x. 
21. Fortin T, Camby E, Alik M, Isidori M, Bouchet $H$. Panoramic images versus three-dimensional planning software for oral implant planning in atrophied posterior maxillary: A clinical radiological study. Clin Implant Dent Relat Res 2013;15:198-204. doi:10. 1111/j.1708-8208.2011.00342.x.

22. Peleg M, Garg AK, Mazor Z. Predictability of simultaneous implant placement in the severely atrophic posterior maxilla: A 9-year longitudinal experience study of 2132 implants placed into 731 human sinus grafts. Int $]$ Oral Maxillofac Implants 2006;21:94-102.

23. Zinser MJ, Randelzhofer $P$, Kuiper $L$, Zoller JE, De Lange GL. The predictors of implant failure after maxillary sinus floor augmentation and reconstruction: a retrospective study of 1045 consecutive Implants Oral Surg Oral Med Oral Pathol Oral Radiol 2013;115:571-82. doi:10.1016/j.000o. 2012.06.015.

24. Alsaadi G, Quirynen M, Komárek A, Van Steenberghe $D$. Impact of local and systemic factors on the incidence of oral implant failures, up to abutment connection. J Clin Periodontol 2007; 34:610-7.doi:10.1111/j.1600-051X.2007.01077.x.

25. Gerressen $M$, Hermanns-Sachweh $B$, Riediger $D$, Hilgers R-D, Spiekermann H, Ghassemi A. Purely cancellous vs. corticocancellous bone in sinus floor augmentation with autogenous iliac crest: a prospective clinical trial. Clin Oral Implants Res 2009;20:109-15.doi:10.1111/j.1600-0501.2008. 01619.x.

26. Mardinger O, Chaushu G, Sigalov S. Factors affecting changes in sinus graft height between and above the placed Implants Oral Surg Oral Med Oral Pathol Oral Radiol Endod. 2011;111:e6-e11. doi:10.1016/j.tripleo.2010.09.064.

27. Özkan Y, Akoğlu B, Kulak-Özkan Y. Maxillary sinus floor augmentation using bovine bone grafts with simultaneous implant placement: a 5-year prospective follow-up study. Implant Dent 2011;20:455-9.

28. Kim Y-K, Yun P-Y, Kim S-G, Kim B-S, Ong JL. Evaluation of sinus bone resorption and marginal bone loss after sinus bone grafting and implant placement. Oral Surg Oral Med Oral Pathol Oral Radiol Endod. 2009;107:e21-8.doi:10.1016/j. tripleo. 2008.09.033.
29. Al-Nawas B, Schiegnitz E. Augmentation procedures using bone substitute materials or autogenous bone - a systematic review and meta-analysis. Eur J Oral Implantol 2014;7:219-34.

30. Ali SA, Karthigeyan S, Deivanai M, Kumar A. Implant Rehabilitation For Atrophic Maxilla: A Review. J Indian Prosthodont Soc 2014;14:196-207.

31. Maiorana C, Sigurta D, Mirandola A, Garlini G, Santoro F. Sinus elevation with alloplasts or xenogenic materials and implants: an up-to-4-year clinical and radiologic follow-up. Int J Oral Maxillofac Implants 2006;21:426-32.

32. Tidwell JK, Blijdorp PA, Stoelinga PJW, Brouns JB, Hinderks $F$. Composite grafting of the maxillary sinus for placement of endosteal Implants A preliminary report of 48 patients. Int J Oral Maxillofac Surg 1992;21:204-9.

33. Borges FL, Dias RO, Piattelli $A$, et al. Simultaneous sinus membrane elevation and dental implant placement without bone graft: a 6-month follow-up study. J Periodontol 2011;82:403-12.

doi:10.1902/jop.2010.100343.

34. Thor A, Sennerby L, Hirsch JM, Rasmusson L. Bone Formation at the Maxillary Sinus Floor Following Simultaneous Elevation of the Mucosal Lining and Implant Installation Without Graft Material: An Evaluation of 20 Patients Treated With 44 Astra Tech Implants J Oral Maxillofac Surg 2007;65:64-72. doi:10.1016/j.joms.2006.10.047.

35. Canullo L, Patacchia O, Sisti A, Heinemann F. Implant restoration 3 months after one stage sinus lift surgery in severely resorbed maxillae: 2-year results of a multicenter prospective clinical study. Clin Implant Dent Relat Res 2012;14:412-20. doi:10.1111/j.1708-8208.2009.00261.x.

\section{Yazışma Adresi}

Yrd. Doç. Dr. Adnan KILINÇ

Ataturk University Faculty of Dentistry,

Department of Oral and Maxillofacial Surgery, 25030, Erzurum, Turkey

e-mail: adnankilin@yahoo.com

Tel: +90 4422311734

Fax:+90 4422361375 